\title{
Magmatic Systems and the Conditions for Hydrothermal Circulation at Depth in the Klyuchevskoi Volcanic Cluster as Inferred from Observations of Local Seismicity and Thermo-Hydrodynamic Simulation
}

\author{
A. V. Kiryukhin ${ }^{a, *}$, S. A. Fedotov ${ }^{a}$, and P. A. Kiryukhin ${ }^{b}$ \\ ${ }^{a}$ Institute of Volcanology and Seismology, Far East Branch, Russian Academy of Sciences, Bul'var Piipa, 9, \\ Petropavlovsk-Kamchatskii, 683006 Russia \\ ${ }^{b}$ EPAM, Zastavskaya, 22-2, Mega-Park, St. Petersburg, 196084 Russia \\ *e-mail: AVKiryukhin2@mail.ru \\ Received October 26, 2017
}

\begin{abstract}
An analysis of local seismicity within the Klyuchevskoi Volcanic Cluster and Shiveluch Volcano for the period 2000-2017 revealed a sequence of plane-oriented earthquake clusters that are interpreted here as the emplacement of dikes and sills (magmatic fracking). The geometry of magma bodies reflects the geomechanical conditions in volcanic plumbing systems and at the bases of the volcanoes. Magmatic fracking within active magmatic plumbing systems results in the formation of permeable reservoirs whose vertical extent can reach $35 \mathrm{~km}$ (Klyuchevskoi) and can be as wide as $15 \mathrm{~km}$ across (Shiveluch), depending on the geomechanical condition of the host rocks. These reservoirs will be the arena of subsequent hydrothermal circulation, producing geothermal and ore fields, as well as hydrocarbon fields. TOUGH2-EOS1sc simulation tools were used to estimate the conditions for the formation of hydrothermal reservoirs at temperatures below $1200^{\circ} \mathrm{C}$ and pressures below 1000 bars.
\end{abstract}

DOI: $10.1134 / \mathrm{S} 0742046318040036$

\section{INTRODUCTION}

The Klyuchevskoi Volcanic Cluster includes several active volcanoes, viz., Klyuchevskoi, Krestovskii, Ushkovskii, Bezymyannyi, and Ploskii Tolbachik. Shiveluch, an active volcano, stands $80 \mathrm{~km}$ northeast of Klyuchevskoi. The Klyuchevskoi giant stratovolcano (which is younger than 7000 years) has the highest output, producing an average yearly discharge of 60 million tons of basalt, which is $25 \%$ of the total annual amount of rocks that are discharged by all 70 volcanoes in the Kuril-Kamchatka volcanic belt. Klyuchevskoi Volcano has been under detailed seismological and volcanological observation since 1935; the results can be found in numerous works and reviews (Fedotov, 2006; Fedotov and Zharinov, 2007; Fedotov et al., 2014). In recent years, seismic tomography yielded data on the filling/draining dynamics for the magmatic plumbing system of Klyuchevskoi (Koulakov et al., 2013). Information on the hydrogeological and geotemperature conditions in the volcanogenic basin of the Klyuchevskoi Volcanic Cluster can be found in (Kiryukhin et al., 2010; Kirsanova and Yurova, 1979); the last reference contains the hypothesis that thermal waters are present in the Tolbachik Dol basin.

Descriptions of hydrothermal circulation in the magmatic plumbing systems beneath volcanoes also have important applications to the prediction of volcanic eruptions, the assessment of geothermal resources, the conditions that favor the formation of geothermal, ore, and some types of oil-and-gas fields, as well as in connection with the technologies used to create circulation systems (by the hydraulic fracture method) for extraction or burial of various fluids (EGS ("hot dry rocks"), shale gas, hardly extractable oil, etc.).

One of the most fundamental causes that facilitates the transport of fluids in the upper brittle shell of the crust consists of hydraulic fracturing and activation of critically compressed plane-oriented cracks and faults during crustal evolution (Zoback, 2010). Shapiro (2008) showed that a diffusion mechanism operates in the propagation of a microseismicity front during the injection of water to create underground geothermal circulation systems. In contrast to water, the injection of magma beneath active volcanoes is accompanied by the formation of dike fields and sills in discrete systems of cracks whose orientation is controlled by geomechanical conditions and by geologic structure (Kiryukhin et al., 2016, 2017; Kiryukhin et al., 2017). A theoretical feasibility study for possible uses of local seismicity data to detect an episode of magma injection in a crack beneath an active volcano was made by Kiryukhin (2017).

Discrete systems of plane-oriented earthquake clusters in the area of the Klyuchevskoi Volcanic Clus- 
ter that are interpreted as highly permeable zones of magmatic fracking are identified using FracDigger software (state registered under no. 2016616880); the relevant algorithms are described in (Kiryukhin et al., 2016, 2017; Kiryukhin et al., 2017). We wish to note here that, unlike the algorithm for identification of plane-oriented earthquake clusters (Makeev et al., 2011), FracDigger software uses a time-dependent criterion for sampling. The raw data are contained in seismic catalogs compiled by the Kamchatka Branch Federal Research Center Unified Geophysical Survey Russian Academy of Sciences (KB FRC UGS RAS) based on observations by local seismic networks within active volcanoes in Kamchatka for the period 2000-2017. Our thermo-hydrodynamic simulation of hydrothermal circulation in volcanic systems used the iTOUGH2-EOS1sc software (Magnúsdóttir and Finsterle, 2015), in which the model can reproduce conditions for two-phase non-isothermic filtering in a cracked porous medium at temperatures between 2 and $1200^{\circ} \mathrm{C}$ and pressures between 0.2 and 1000 bars.

\section{MAGMA INJECTION IN THE AREA OF THE KLYUCHEVSKOI VOLCANIC CLUSTER FOR 2000-2017 AS INFERRED FROM OBSERVATIONS OF LOCAL SEISMICITY}

To recover the sequence of magma injections in the area of the Klyuchevskoi Volcanic Cluster we used a catalog containing data of seismic monitoring at 19 seismic stations operated by the KB FRC UGS RAS for the 2000-2017 period (the total number of earthquakes that have been recorded between January 1, 2000 and August 23, 2017 is 122 451). The method that we used to identify plane-oriented earthquake clusters and fitting planes using the FracDigger software was described in (Kiryukhin et al., 2016, 2017; Kiryukhin et al., 2017). The relevant calculated plane patches are interpreted as zones of magma emplacement in the form of dikes and sills. The calculations assumed the following parameters for identification of plane-oriented clusters: interevent time within 30 days, the interevent distance in the horizontal plane was $6 \mathrm{~km}$, and the standard deviation from the plane was $1000 \mathrm{~m}$. The calculations yielded 1788 clusters that contained 117412 earthquakes $(96 \%$ of the total number of recorded events) (Figs. 1 through 6).

A vertical profile along the axis of the Klyuchevskoi Volcanic Cluster (see Fig. 2) that extends from the Tolbachik volcanoes to Shiveluch shows that when extrapolated downward the dikes beneath Tolbachik and Shiveluch intersect at a point that lies between absolute heights of -165 and $-205 \mathrm{~km}$ beneath Klyuchevskoi; it is at this location that the region of primary magma melting is thought to reside, or there is a primary magma chamber to provide magma for all active volcanoes in the Klyuchevskoi Cluster (Kly- uchevskoi, Ploskii Tolbachik, Bezymyannyi, and Shiveluch).

The 2000-2017 magma injections directly beneath Klyuchevskoi were concentrated in the depth ranges between -31 and $-28 \mathrm{~km}$ abs. (35\%) and between -1 and $+2 \mathrm{~km}$ abs. (20\%) where we hypothesize the existence of a crustal chamber $(\mathrm{C} 2)$ and a peripheral chamber (C1), respectively (see Figs. 2 and 3 ). The crustal magma chamber (C2) was found to contain dikes that dip at angles of $70^{\circ}-80^{\circ}(30 \%)$ and sills that dip at $15^{\circ}-20^{\circ}(8 \%)$; one also notes an increasing number of nearly east-west striking dikes that supply magma to the nearby Bezymyannyi and Krestovskii volcanoes. Nine episodes of intensive dike emplacement and seven episodes of intensive sill emplacement were recorded in $\mathrm{C} 2$ chamber during the period of interest (2000-2017); the dike episodes preceding the sill episodes by an advance time of 1 year (two cases), the episodes occurred simultaneously (five cases), or else did not terminate in sill emplacement (one case), which provides evidence of a change in the geomechanical condition around the $\mathrm{C} 2$ chamber in the range from horizontal tension to radial compression. The dip angles and azimuths of dikes and sills in the peripheral chamber $(\mathrm{C} 1)$ are distributed rather uniformly; one notes some increase in the number of dikes that dip at angles of $35^{\circ}-50^{\circ}$ and $65^{\circ}-80^{\circ}$; as well, there is a set of dikes that dip at northeast azimuths (that is, striking along the KlyuchevskoiKrestovskii line).

Tolbachik Volcano is characterized by injections of magma in the depth range between -8 and $-1 \mathrm{~km}$ abs., with most dikes dipping more steeply than $60^{\circ}(67 \%)$ (see Fig. 4); as well, we identified a set of dikes that dip at $180^{\circ}-220^{\circ}(26 \%)$ and trending along the Ostryi Tolbachik to Ploskii Tolbachik to the Bol'shaya Undina line.

Shiveluch is characterized by magma injections in the depth ranges between -4 and $-2 \mathrm{~km}$ abs. (37\%) and between 0 and $+2 \mathrm{~km}(47 \%)$, where two peripheral magma chambers are hypothesized to reside (see Fig. 5). The injections mostly occurred in the form of sills that dip at angles below $5^{\circ}$, with some trend of prevailing western dip azimuths.

Bezymyannyi Volcano receives magma from the crustal magma chamber beneath Klyuchevskoi Volcano (C2), which lies at a depth between -31 and $-28 \mathrm{~km}$ abs. (see Figs. 2 and 6). The injections beneath Bezymyannyi occurred in the depth range between -2 and $+2 \mathrm{~km}(93 \%)$ where a peripheral magma chamber is hypothesized to exist (see Fig. 6). The injections mostly occurred in the form of sills that dip at angles below $15^{\circ}(27 \%)$ and low-angle dikes that dip at $50^{\circ}$ or less (58\%); the dip azimuths are distributed uniformly over all directions.

The volumes of magma injection from magma chambers can be estimated using empirical relationships that relate the maximum magnitude of the trig- 


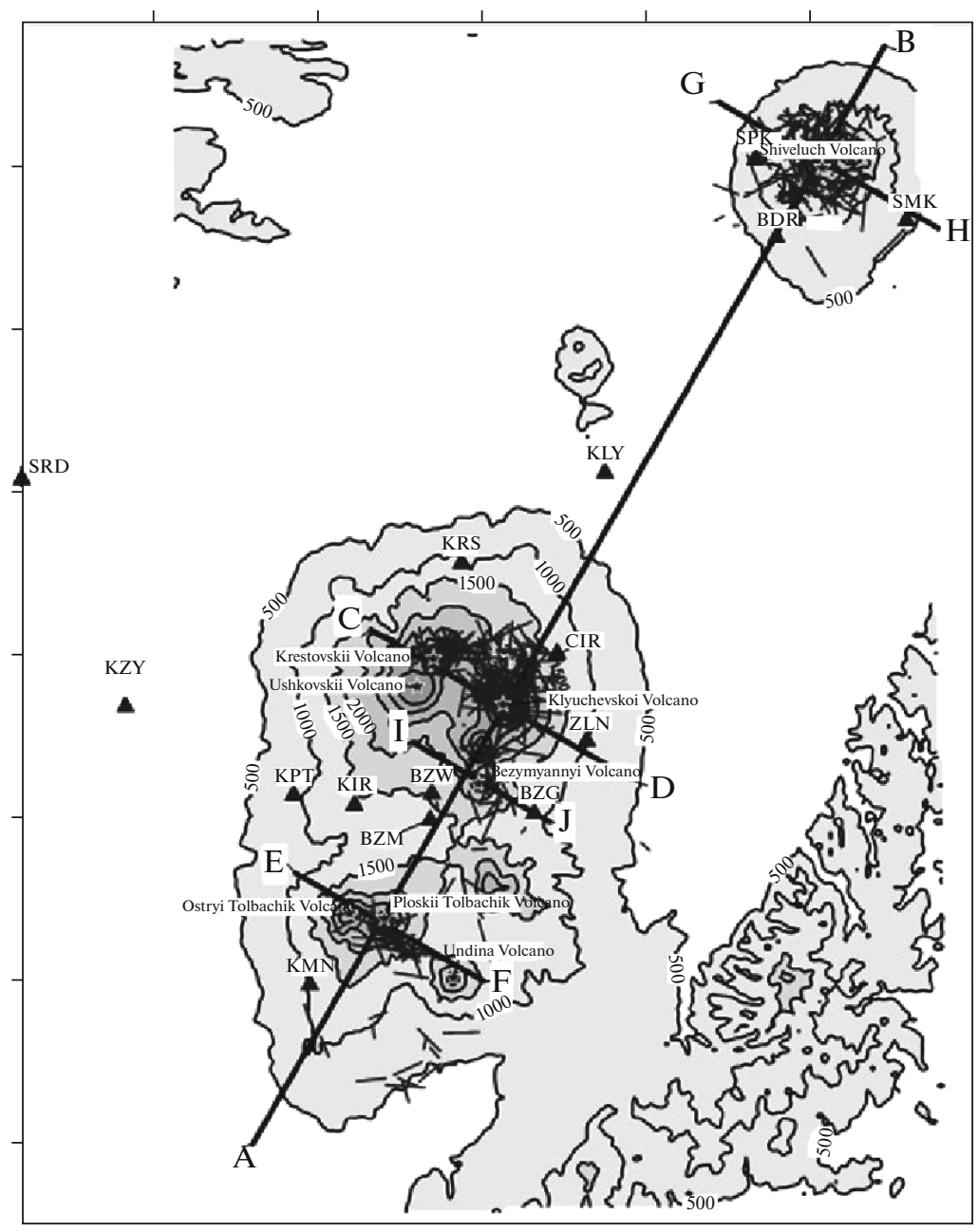

Fig. 1. A sketch map of the Klyuchevskoi Volcanic Cluster showing the topographic surface, the locations of seismic stations (triangles), and vertical sections AB, CD, EF, GH, and IJ (see Figs. 2 through 6). This figure also shows dikes (intersections of planeoriented earthquake clusters with the horizontal plane at $-3000 \mathrm{~m}$ abs.). The tick marks on the axes are at intervals of $10 \mathrm{~km}$.

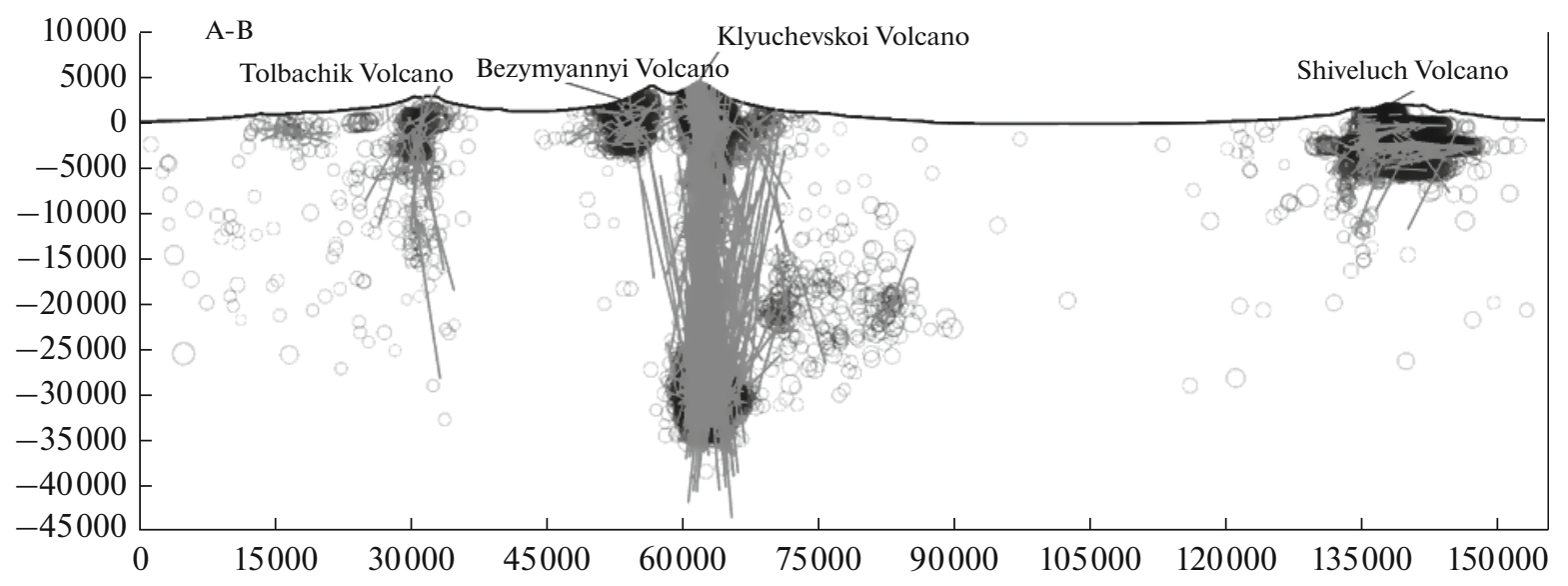

Fig. 2. The distribution of dikes (intersections of plane-oriented earthquake clusters with a vertical plane) and earthquake hypocenters (2000-2017, as reported by the KB FRC UGS RAS) on vertical section AB (the location of this section can be seen in Fig. 1). 


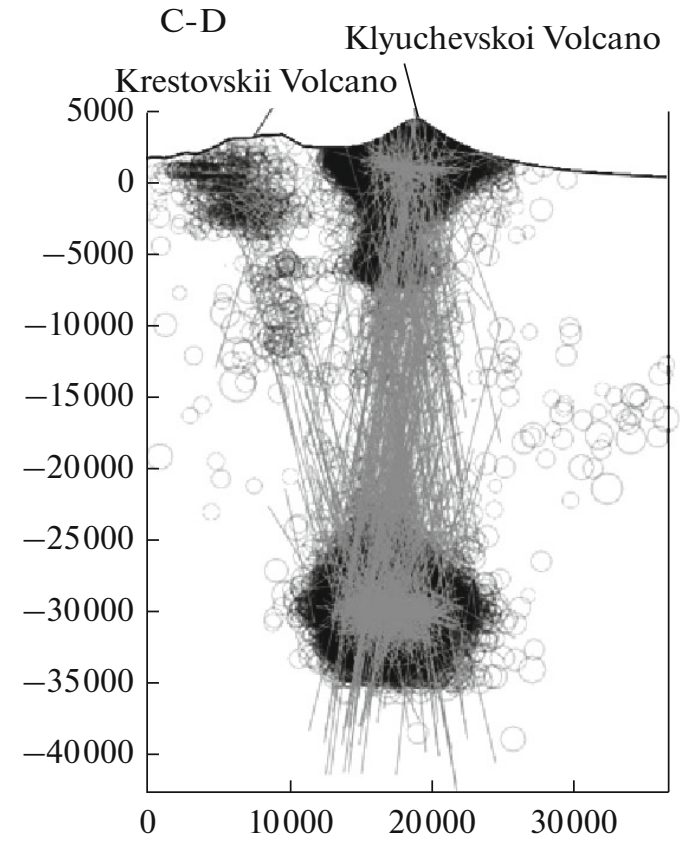

Fig. 3. The distribution of dikes (intersections of planeoriented earthquake clusters with a vertical plane) and earthquake hypocenters (2000-2017, as reported by the KB FRC UGS RAS) on vertical section CD (the location of this section can be seen in Fig. 1).

gered seismicity to the volume of injected magma (Fujii et al., 2018, personal communication):

$$
M=0.67 \log (V)-0.82,
$$

where $M$ is the maximum magnitude of triggered seismic events and $V$ is the injection volume. The results from this assessment of dike and sill injections for the volcanoes in the Klyuchevskoi Cluster during 20002017 using (1) are listed in Table 1. Assuming the enthalpy of magma at a temperature of $1200^{\circ} \mathrm{C}$ to be $H_{m} \approx 1000 \mathrm{~kJ} / \mathrm{kg}$ and the density of magma to be $\rho=$

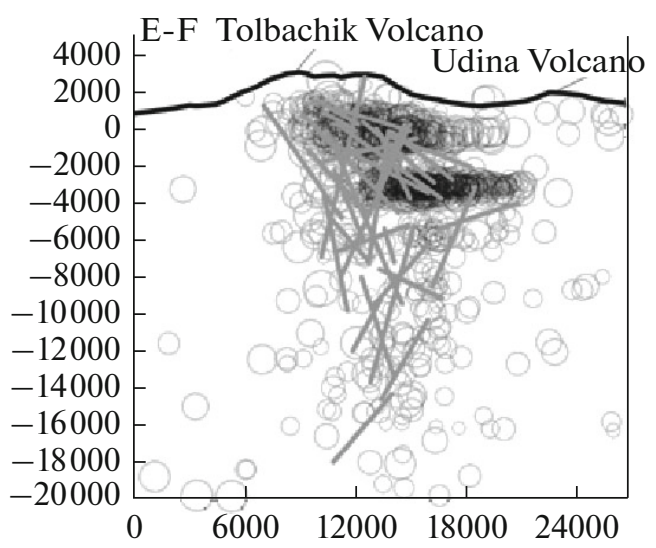

Fig. 4. The distribution of dikes (intersections of planeoriented earthquake clusters with a vertical plane) and earthquake hypocenters (2000-2017, as reported by the KB FRC UGS RAS) on vertical section EF (the location of this section can be seen in Fig. 1).

$2800 \mathrm{~kg} / \mathrm{m}^{3}$, one can estimate the mass discharge $Q$ and the power of the thermal sources $q$ due to magma injections:

$$
\begin{gathered}
Q=\frac{V \rho}{\Delta t}, \\
q=Q H_{m},
\end{gathered}
$$

where $\Delta t$ is the time elapsed from January 1, 2000 to August 23, 2017. The thermal power values for magma injections in the volcanic plumbing systems considered here as calculated from (2) are also listed in Table 1.

Comparison between the estimates for mass discharges of magma injection beneath volcanoes as listed in Table 1 and the output estimates for the respective volcanoes from (Polyak and Melekestsev, 1981) yields the following ratios between the discharge of magmas stored beneath volcanoes and that of magma ejected onto the ground surface: $0.8 \%$ for Kly-

Table 1. The calculated volumes of magma injections in magma chambers beneath volcanoes and the associated thermal power values for $2000-2017$

\begin{tabular}{l|c|c|c|c}
\hline \multicolumn{1}{c|}{ Volcano } & Depth range, km abs. & max. magnitude & $\begin{array}{c}\text { Volume, } \\
\text { million } \mathrm{m}^{3}\end{array}$ & $\begin{array}{c}\text { Thermal power, } \\
\text { MW (magma discharge } \\
\text { is in } \mathrm{kg} / \mathrm{s})\end{array}$ \\
\hline $\begin{array}{l}\text { Klyuchevskoi (peripheral } \\
\text { chamber C1) }\end{array}$ & $-31 \ldots-28$ & 3.05 & 0.6 & 3.0 \\
$\begin{array}{l}\text { Klyuchevskoi (crustal } \\
\text { chamber C2) }\end{array}$ & $-1 \ldots+2$ & 3.45 & 2.4 & 11.9 \\
Bezymyannyi & $-2 \ldots+2$ & 3.65 & 4.7 & 23.6 \\
Tolbachik & $-8 \ldots-1$ & 3.95 & 13.2 & 66.2 \\
Shiveluch & $-4 . . .-2,0 \ldots+2$ & 4.1 & 22.0 & 110.9 \\
\hline
\end{tabular}




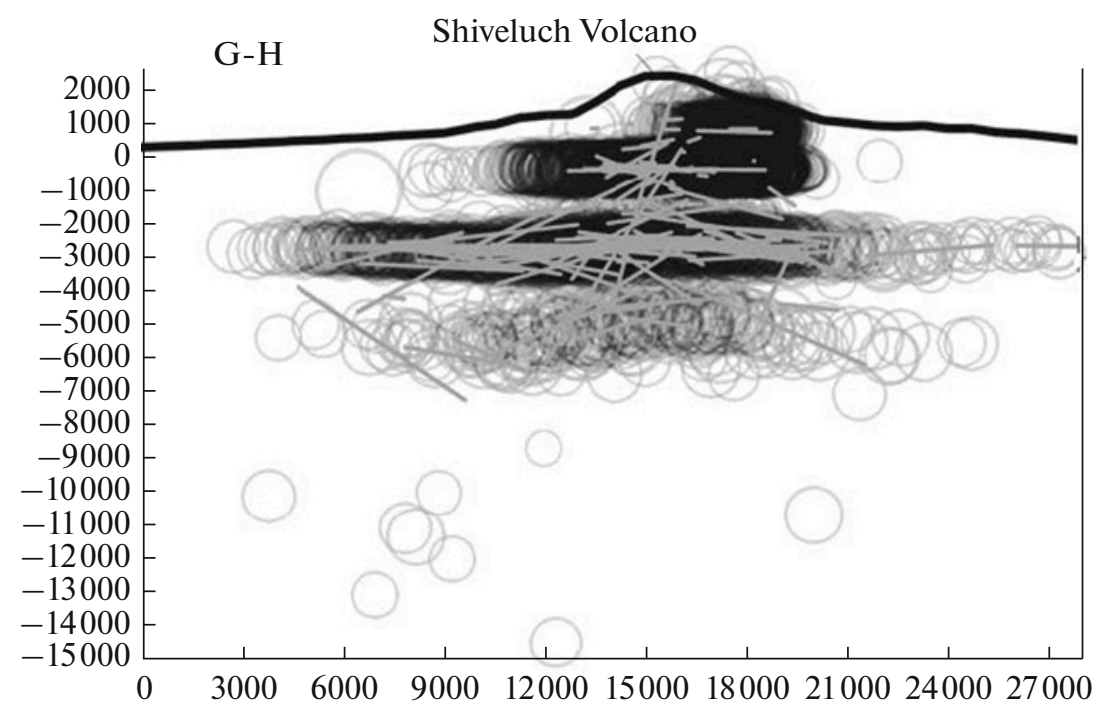

Fig. 5. The distribution of dikes (intersections of plane-oriented earthquake clusters with a vertical plane) and earthquake hypocenters (2000-2017, as reported by the KB FRC UGS RAS) on vertical section GH (the location of this section can be seen in Fig. 1).

uchevskoi, $14.9 \%$ for Bezymyannyi, $23.2 \%$ for Tolbachik, and $72.9 \%$ for Shiveluch.

\section{THE GEOMECHANICAL CONDITIONS BENEATH KLYUCHEVSKOI, BEZYMYANNYI,} TOLBACHIK, AND SHIVELUCH VOLCANOES

The orientations of the dikes and sills that are due to magma injections beneath volcanoes are indicators of the geomechanical conditions in the respective locations. We shall keep, as far as is possible, to the classification of geomechanical conditions as defined by Anderson (Zoback, 2010) based on the relationships among vertical stress $\mathrm{S}_{\mathrm{v}}$, maximum horizontal stress $S_{\mathrm{Hmax}}$, and minimum horizontal stress $\mathrm{S}_{\mathrm{hmin}}$ (or, incorporating the fluid (pore) pressure, the respective effective stresses $\left.\sigma_{\mathrm{v}}, \sigma_{\mathrm{Hmax}}, \sigma_{\mathrm{hmin}}\right)$. In particular, the NF conditions (normal faults, the formation of normal faults) are found when $\mathrm{S}_{\mathrm{v}}>\mathrm{S}_{\mathrm{H} \max }>\mathrm{S}_{\mathrm{hmin}}$; the SS (strike-slip) conditions arise with $\mathrm{S}_{\mathrm{H} \max }>\mathrm{S}_{\mathrm{v}}>\mathrm{S}_{\mathrm{hmin}}$; and the RF (reverse fault) conditions are found when $\mathrm{S}_{\mathrm{Hmax}}>\mathrm{S}_{\mathrm{hmin}}>\mathrm{S}_{\mathrm{v}}$. It is also assumed that hydraulic fracture cannot occur unless the fluid pressure exceeds the minimum stress, the plane of the hydraulic fracture crack is perpendicular to its direction, and the crust is in a frictional equilibrium (that is, the minimum and maximum effective stresses are related via the Mohr criterion of failure). Our stress calculations will be based on data from (Fedotov et al., 2014).

The orientations of those dikes and sills in the crustal magma chamber beneath Klyuchevskoi Volcano (C2) that are emplaced simultaneously suggest the NF geomechanical conditions for radial stress $\left(\sigma_{\mathrm{v}}>\sigma_{\mathrm{H} \max }=\sigma_{\mathrm{hmin}}\right)$ that produce steeply dipping dikes striking at various directions and going from the bot- tom and top of a partially molten magma chamber that is under a radial lateral compression $\mathrm{RF}\left(\sigma_{\mathrm{v}}<\sigma_{\mathrm{H} \max }=\right.$ $\sigma_{\text {hmin }}$ ) at a depth between -31 and $-28 \mathrm{~km}$ abs. (see Fig. 3).

The peripheral magma chamber beneath Klyuchevskoi (C1) is generally in the geomechanical condition involving the maximum radial stress; hence, dikes are injected at various angles and azimuths of dip (see Fig. 3). Anderson's geomechanical concept is inapplicable in this particular case.

The Tolbachik volcanoes are in the NF geomechanical conditions with the axis of the tension zone

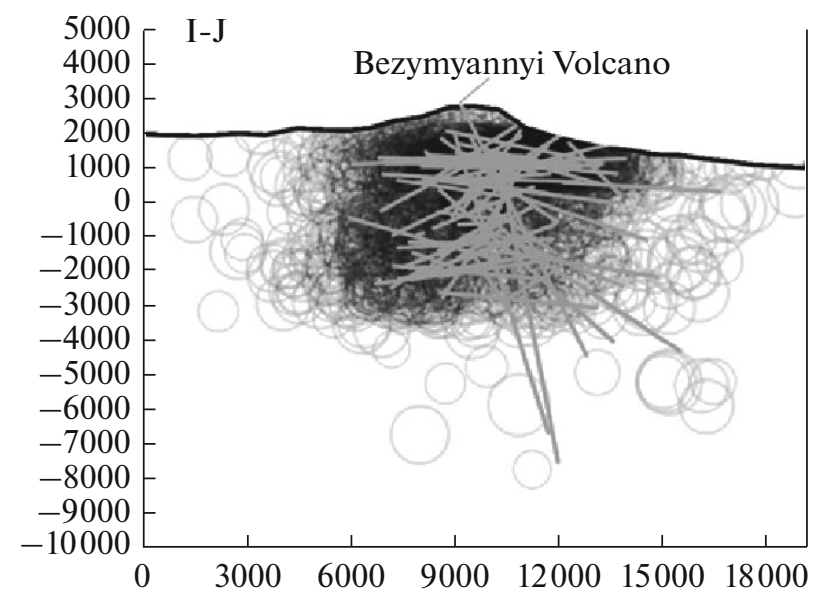

Fig. 6. The distribution of dikes (intersections of planeoriented earthquake clusters with a vertical plane) and earthquake hypocenters (2000-2017, as reported by the KB FRC UGS RAS) on vertical section IJ (the location of this section can be seen in Fig. 1). 
Table 2. The filtering and capacity properties and petrophysical parameters of rocks as determined by simulation

\begin{tabular}{l|c|c|c|c|c|c}
\hline \multirow{2}{*}{\multicolumn{1}{c|}{ Parameters }} & \multicolumn{5}{|c}{ Domains in model } \\
\cline { 2 - 6 } & ROCK1 & ROCK2 & FRAC1 & FRAC2 & $\begin{array}{c}\text { BON1 } \\
\text { (Fixed State) }\end{array}$ & $\begin{array}{c}\text { BON2 } \\
\text { (Fixed State) }\end{array}$ \\
\hline Permeability, $10^{-15} \mathrm{~m}^{2}$ & 0.1 & 0.1 & 100 & 100 & 0.1 & 0.1 \\
Porosity & 0.001 & 0.001 & 0.01 & 0.01 & \\
Mineral density, $\mathrm{kg} / \mathrm{m}^{3}$ & 2600 & 2600 & 2600 & 2600 & 2.0 \\
Thermal conductivity, $\mathrm{W} / \mathrm{m}^{\circ} \mathrm{C}$ & 2.0 & 2.0 & 2.0 & 2.0 & 2.0 \\
\hline
\end{tabular}

The relative permeabilities are given by Corey functions with $\mathrm{S}_{\mathrm{lr}}=0.3, \mathrm{~S}_{\mathrm{gr}}=0.05$, specific heat $1000 \mathrm{~J} / \mathrm{kg}{ }^{\circ} \mathrm{C}$ is specified for all domains in the model. Density, porosity, and thermal conductivity are based on data from (Chernyak et al., 1987), permeability is specified by analogy with known thermal fields (Kiryukhin, 2002; Kiryukhin et al., 2008; Kiryukhin et al., 2017).

along the Ostryi Tolbachik to Ploskii Tolbachik to Bol'shaya Undina line (the azimuth is west-northwest, $290^{\circ}$ ) (see Fig. 1). However, the 2012 eruption produced a change in the geomechanical conditions to become RF lateral compression, as a result of increased magma pressure, producing sills at a depth of approximately $0 \mathrm{~km}$ abs. and a magma-conducting dike striking north-northeast (Kiryukhin et al., 2016).

Shiveluch Volcano is characterized by radial lateral compression (RF) with a minimum vertical effective stress $\left(\sigma_{\mathrm{v}}<\sigma_{\mathrm{Hmax}}=\sigma_{\mathrm{hmin}}\right)$, which favors the formation of sills in the depth ranges between -4 and $-2 \mathrm{~km}$ abs. and between 0 and $+2 \mathrm{~km}$ abs. The lower zone of sill production is approximately $17 \mathrm{~km}$ across and the upper is approximately $5 \mathrm{~km}$ (see Fig. 5).

Bezymyannyi Volcano is also characterized by radial lateral compression (RF) with a minimum vertical effective stress $\left(\sigma_{\mathrm{v}}<\sigma_{\mathrm{H} \max }=\sigma_{\mathrm{hmin}}\right)$, which favors the formation of sills in the depth range between -2 and $+2 \mathrm{~km}$ abs.; the zone of sill production is approximately $8 \mathrm{~km}$ across (see Fig. 6). Magma is supplied from the crustal chamber beneath Klyuchevskoi (C2).

\section{TOUGH2 SIMULATION OF THE HYDROTHERMAL CIRCULATION AT DEPTH \\ 4.1. A conceptual model for hydrothermal circulation at depth}

We consider the thermo-hydrodynamic conditions for hydrothermal circulation at depth in cracked reservoirs that were formed by magmatic fracking at the base of an active volcanic plumbing system using data on volcanoes in the Klyuchevskoi Cluster. Such circulation can obviously occur only as far down as the depths of brittle rock failure; these are estimated from seismic data for Klyuchevskoi as approximately $-35 \mathrm{~km}$ abs., $-13 \mathrm{~km}$ abs. for the Tolbachik volcanoes, and approximately $-6 \mathrm{~km}$ abs. for Shiveluch (see Figs. 2, 3, 4 , and 5). The geothermal gradient in the Klyuchevskoi Volcanic Cluster area is $24^{\circ} \mathrm{C} / \mathrm{km}$, showing that temperatures of $850^{\circ} \mathrm{C}, 322^{\circ} \mathrm{C}$, and $164^{\circ} \mathrm{C}$ can be reached at the respective depths, as occurs based on formal calculations. Down-going infiltration of cold water from volcanic edifices must be accompanied by the formation of natural circulation systems and by a redistribution of temperature with possible formation of productive hydrothermal reservoirs. Drilling in high-temperature hydrothermal reservoirs worldwide shows that the highest temperature to be reached for hydrothermal circulation under hydrostatic pressure conditions is $340-350^{\circ} \mathrm{C}$ (Kiryukhin et al., 1991). It thus appears that one can estimate the lowest rate of water recharge to still provide hydrothermal circulation at depth in the magmatic fracking systems of the Klyuchevskoi Volcanic Cluster in the range of the highest temperature of $340-350^{\circ} \mathrm{C}$ and over times of 5000 to 7000 years. Such estimates can be derived using the TOUGH2 method of thermo-hydrodynamic simulation (Pruess et al., 1999) using the magmatic fracking reservoir system of Klyuchevskoi Volcano.

\subsection{A description of the TOUGH2 model and simulation results}

Our 2D thermo-hydrodynamic simulation for the section plane (Fig. 7) was carried out using a model with the following characteristics:

(1) the model geometry extends from the topographic surface to a depth of $-35 \mathrm{~km}$ abs.;

(2) the computation grid is rectangular at steps of $1 \mathrm{~km}$ in $\mathrm{X}$ and in $\mathrm{Z}$;

(3) the material properties include a permeable domain of the magmatic fracking zone (permeability of $1 \mathrm{e}-13 \mathrm{~m}^{2}$ ) and an impermeable domain of the host rocks (permeability of $1 \mathrm{e}-16 \mathrm{~m}^{2}$ ). Table 2 gives a summary of the petrophysical and the filtration and capacity properties as defined for the model;

(4) the boundary atmospheric conditions include a constant pressure of 1 bar and a temperature of $10^{\circ} \mathrm{C}$ at the topographic surface (domain BON1) and the presence of discharge zones at the left and right boundaries of the model ( 1 bar at a height of $0 \mathrm{~m}$ abs., BON2 domain); these are proper to the draining of the volcanogenic basin in the Klyuchevskoi Volcanic Cluster by the Kamchatka and Khapitsa rivers; 


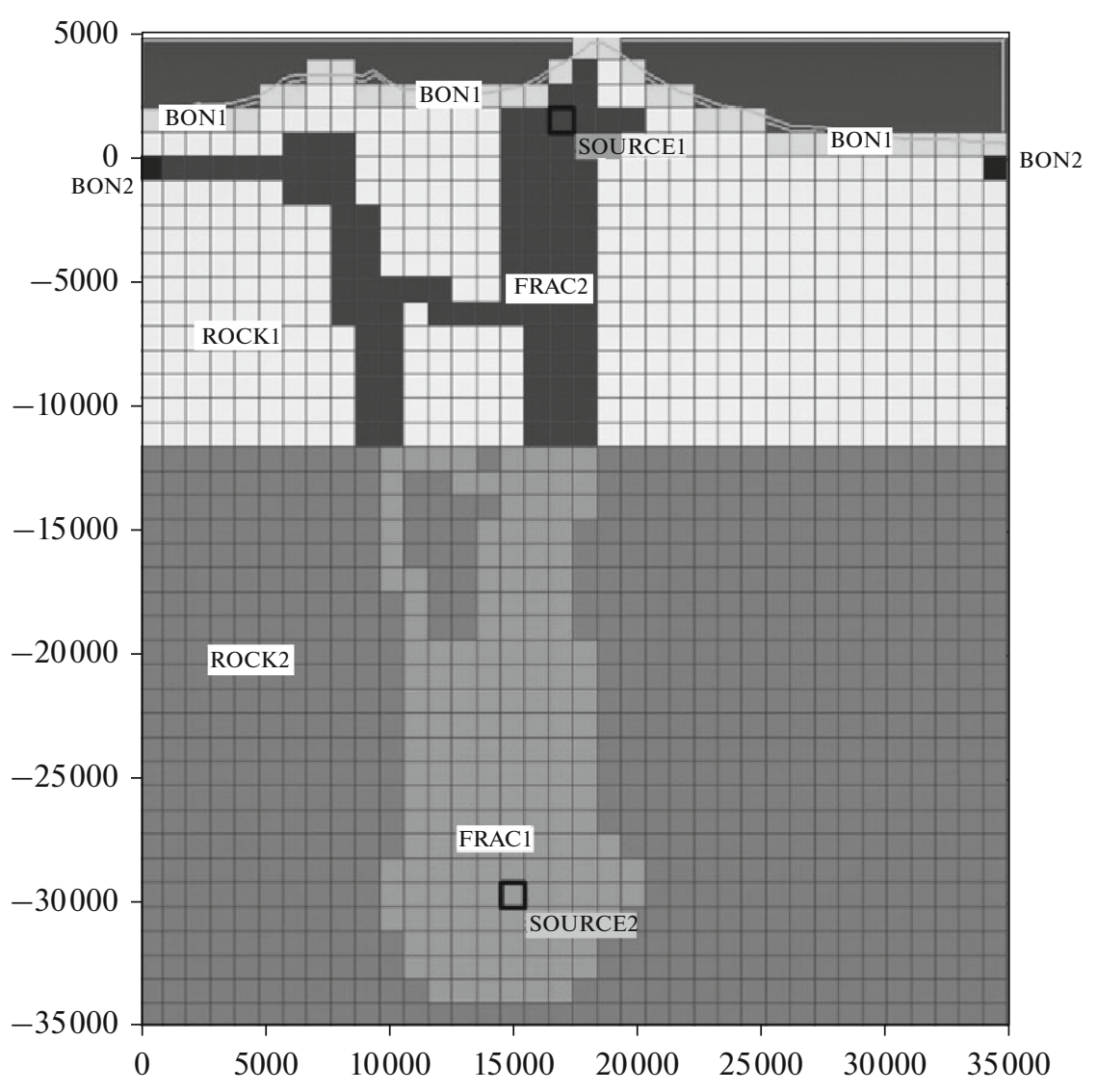

Fig. 7. The geometry of the TOUGH2 model used for analysis of hydrothermal circulation beneath Klyuchevskoi Volcano.

(5) the initial conditions include a hydrostatic distribution of pore pressure and a linearly increasing temperature with increasing depth $\left(24^{\circ} \mathrm{C} / \mathrm{km}\right)$ down to a depth of $10 \mathrm{~km}$; below that level the initial temperature was set at $340^{\circ} \mathrm{C}$;

(6) thermal sources of 12 MW (SOURCE2) and 3 MW (SOURCE1) that are consistent with the heat release due to dike injections into the crustal and the peripheral chamber, respectively, see Table 1;

(7) conductive heat flow at the base of the model is $60 \mathrm{e}-3 \mathrm{~W} / \mathrm{m}^{2}$;

(8) the simulation time is 10000 years.

The lower boundary of the model was limited to a depth of $-11.5 \mathrm{~km}$ abs. in the first simulation option, since the range of pressure for the EOS1sc Equation of State module is below 1000 bars. This is proper to the depth as indicated above under a hydrostatic pressure distribution. The simulation results, viz., temperature distribution, the saturation of the gas phase, and the field of filtration rate, are shown in Fig. 8. The model shows the formation of two shallow high-temperature hydrothermal reservoirs with a temperature between 220 and $240^{\circ} \mathrm{C}$ (the circulation discharge is $13.6 \mathrm{~kg} / \mathrm{s}$ ) in the magmatic fracking zone beneath Klyuchevskoi Volcano and a temperature between 260 and $280^{\circ} \mathrm{C}$ (the circulation discharge is $12.5 \mathrm{~kg} / \mathrm{s}$ ) in the magmatic fracking zone beneath Krestovskii Volcano. The formation of these reservoirs is due to nearly vertical circulation of water from water recharge regions (as defined by elevated parts of the volcanoes) to the discharge zone at the lateral sides of the model via the transitional zone of thermal convection in permeable zones of magmatic fracking at depth beneath the active volcanoes mentioned above. The thermal supply to the hydrothermal reservoirs is due to redistribution of temperatures in the zones of magmatic fracking and to the inflow of thermal energy from the host rocks, whose temperature is $340^{\circ} \mathrm{C}$. The above mechanism is different from the classical concepts for the formation of high-temperature hydrothermal reservoirs (Kiryukhin et al., 1991), which imply that the presence of magma chambers is required for thermal supply to high-temperature hydrothermal systems.

The second simulation option (Fig. 9) has the lower boundary of the model dropped down to the actual depth of the bottom of the magmatic fracking zone beneath Klyuchevskoi, that is, to a depth of $-35000 \mathrm{~m}$. We note that the very possibility of underground water circulation at that depth is demonstrated by the presence of plane-oriented earthquake clusters there; the clusters provide evidence of brittle deformation to produce 


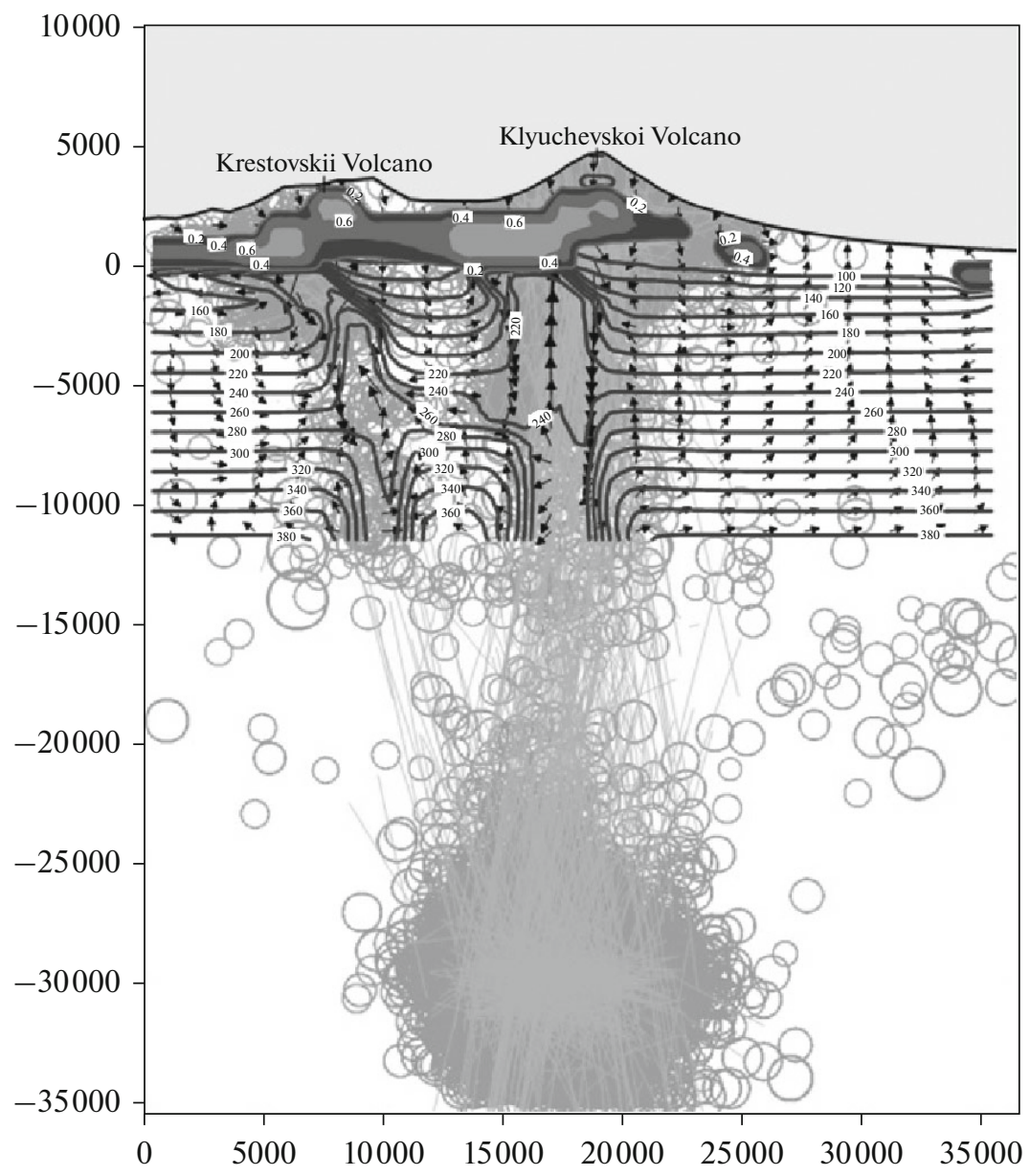

Fig. 8. The results of iTOUGH2-EOS1sc simulation for the distribution of temperature, saturation of the gas phase, and mass flows of fluids in a vertical section passing through Klyuchevskoi and Krestovskii volcanoes (see Fig. 3). The temperature distribution is shown by solid isolines, the distribution of gas phase saturation by grey isolines with shading, and the vectors of mass fluid flows by arrows. The background map is that in Fig. 3. The scales on the axes are in meters. The 12B simulation option is presented in this figure.

hydraulic fracture cracks. To be able to carry out our simulation at these depths we set the value of $g$ (the acceleration due to gravity) equal to $3 \mathrm{~m} / \mathrm{s}^{2}$ in the model. This made it possible to reduce the value of the hydrostatic gradient in order to remain within the range of pressure for the EOS1sc Equation of State module (1000 bars).

In this connection, we wish to note that an analysis of the governing equations of free convection in a vertical permeable zone under the assumption of a linear dependence of water density on temperature and of single-phase filtering shows (Kiryukhin and Sugrobov, 1987 , p. 84 , equations $3.17-3.20$ ) that the discharge of hydrothermal circulation is proportional to $K=\frac{k \rho g}{\mu}$, where $k$ is permeability $\left(\mathrm{m}^{2}\right), \rho$ is water density $\left(\mathrm{kg} / \mathrm{m}^{3}\right), \mu$ is viscosity ( $\left.\mathrm{Pa} \mathrm{s}\right)$, and $g$ the acceleration due to gravity $\left(\mathrm{m} / \mathrm{s}^{2}\right)$. That means that a change in $g$ is equivalent to a proportionate change in permeability (a diminution by a factor of 3.27) in the case considered above.

When a two-phase system is in question, a decrease in $g$ would lead, all other things being equal, to an increased boiling depth; the effect is nonlinear and cannot be compensated while remaining within the framework of this model. We are going to modify the EOS1sc module in the future in order to adapt it to dealing with depths as great as $35 \mathrm{~km}$, when the properties are extrapolated from region 1 (see Fig. 1), (Magnúsdóttir and Finsterle, 2015).

The modeling results, viz., the temperature distribution, the saturation of the gas phase, and the field of filtration rates, are shown in Fig. 9. The model revealed the formation of two shallow high-temperature hydrothermal reservoirs, one at a temperature between 280 and $300^{\circ} \mathrm{C}$ (the circulation discharge is $106.0 \mathrm{~kg} / \mathrm{s}$, or $140 \mathrm{MW}$ ) in the magmatic fracking zone beneath Klyuchevskoi Volcano and the other with a temperature between 280 and $300^{\circ} \mathrm{C}$ (the circulation 


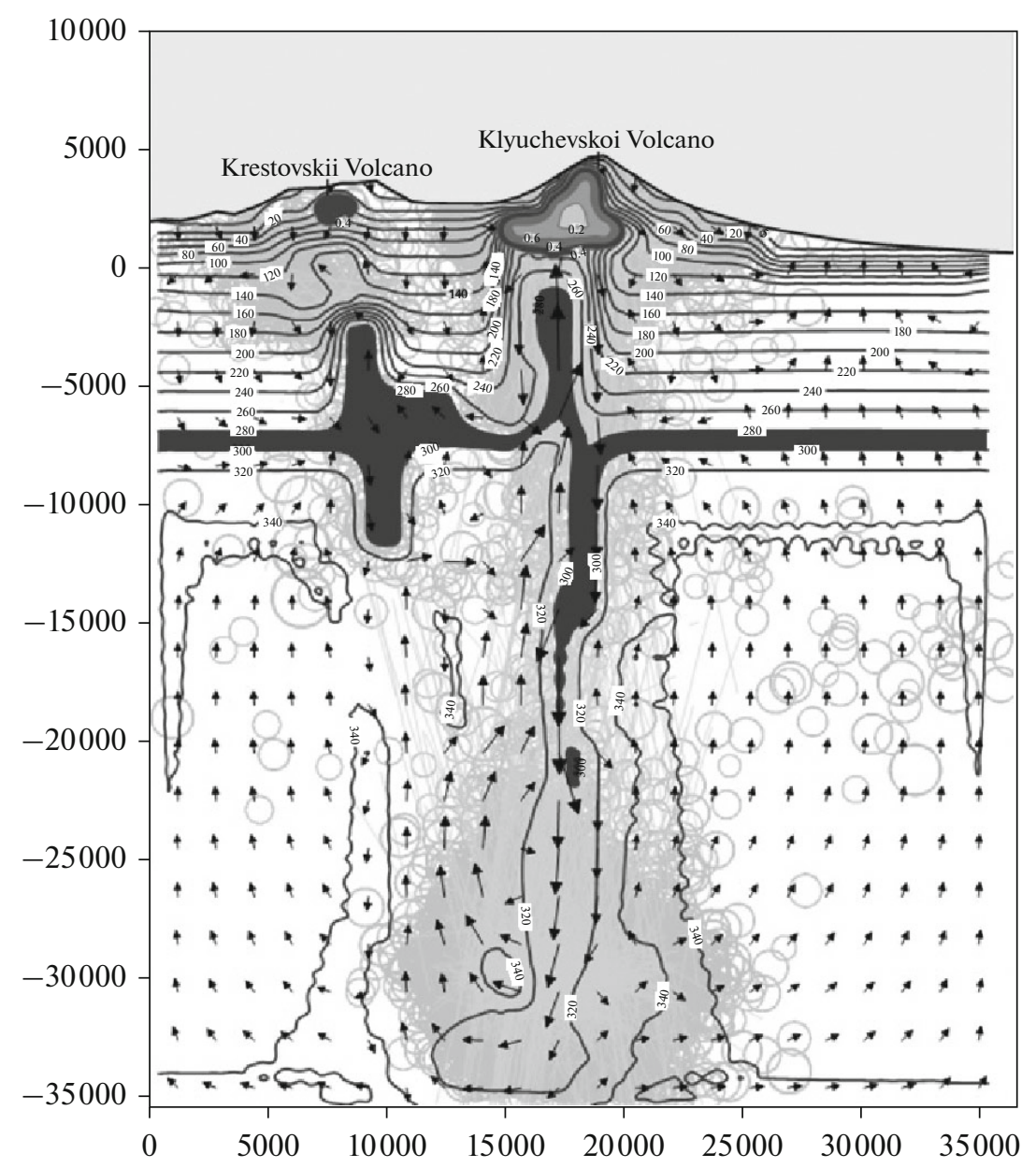

Fig. 9. The results of iTOUGH2-EOS1sc simulation for the distribution of temperature, saturation of the gas phase, and mass flows of fluids in a vertical section passing through Klyuchevskoi and Krestovskii volcanoes (see Fig. 3). The temperature distribution is shown by solid isolines, the distribution of gas phase saturation by grey isolines with shading, and the vectors of mass fluid flows by arrows. The background map is that in Fig. 3. The scales on the axes are in meters. The $12 \mathrm{C}$ simulation option is presented in this figure.

discharge is $12.7 \mathrm{~kg} / \mathrm{s}$, or $18 \mathrm{MW}$ ) in the magmatic fracking zone beneath Krestovskii Volcano. Their origin was due to nearly vertical water circulation from the regions of water recharge (as defined by elevated areas on volcanoes) to the discharge zones at the lateral boundaries of the model via the transitional zone of thermal convection in permeable zones of magmatic fracking at depth beneath the active volcanoes indicated above. Heat is supplied to the hydrothermal reservoirs by redistribution of temperature in the magmatic fracking zones and the inflow of thermal energy from the $340^{\circ} \mathrm{C}$ host rocks.

\section{A DISCUSSION OF THE RESULTS}

There are two points of view on the formation and operation of magma chambers in the Klyuchevskoi Volcanic Cluster area. One was set forth by Fedotov (2006), Fedotov et al. (2011); it is based on the model of a flow-through chamber whose size varies depend- ing on the temperatures of ingoing and outgoing magmas and on the duration and intensity of heat exchange with the host rocks. Such models imply the existence of long-term, homogeneous, ellipsoidal chambers rich in liquid magma beneath the volcanoes. These concepts are based on geological, seismological, and geodetic data, as well as on simulation results for the melting history of the magma chamber. According to these concepts, a peripheral magma chamber is situated under Ploskii Tolbachik Volcano. The chamber is as wide as $6 \mathrm{~km}$, the top is at a depth of $2 \mathrm{~km}$ below sea level, its vertical extent is $3.2-3.9 \mathrm{~km}$, and the volume is $40-70 \mathrm{~km}^{3}$. These concepts are also implied in a geophysical model of the magmatic plumbing system beneath the Klyuchevskoi Volcanic Cluster (Fedotov et al., 2010), which assumes the existence of persistent crustal magma chambers beneath Klyuchevskoi Volcano at depths between -32 and $-26 \mathrm{~km}$ abs. and at depths between -4 and $0 \mathrm{~km}$ abs. $\left(100 \mathrm{~km}^{3}\right)$ and at depths between -20 and $-7 \mathrm{~km}$ abs. $\left(100 \mathrm{~km}^{3}\right)$ 
beneath Bezymyannyi Volcano. Magma can also be stored in thick swarms of sills and dikes that supply magma to the volcanoes.

The other model is based on seismic tomography that revealed the behavior of the $3 \mathrm{D}$ distribution of the compressional to shear wave velocity ratio $V_{\mathrm{p}} / V_{\mathrm{s}}$; an increase in the ratio reveals an increase in the saturation of the liquid phase (magma) beneath the volcanoes (Koulakov et al., 2013). The velocity ratio shows wide variation, indicating two levels of fluid storage beneath Klyuchevskoi Volcano, at a depth of 10-12 km and near the surface. The idea that the fluid is magma is supported by the fact of an increasing velocity ratio during the 2005 eruptions of Klyuchevskoi and Bezymyannyi. The magma reservoirs beneath the Klyuchevskoi Volcanic Cluster are treated as zones of incomplete magma saturation with a rapidly varying (over a few years) saturation of the melt and its rapid pulsating movement in geological space. The existence of a persistent $V_{\mathrm{p}} / V_{\mathrm{s}}$ anomaly at a depth of $12 \mathrm{~km}$ beneath Klyuchevskoi is interpreted as the presence of a fluid passageway from the primary magma source that supplies magma to Klyuchevskoi. The results of seismic tomography are very sensitive to the number and coordinates of hypocenters, which are subject to large variations and show discrepant results among different surveys.

Some additional results were obtained in this paper from a study of the properties of local earthquake clusters beneath the Klyuchevskoi Volcanic Cluster and beneath Shiveluch for 2000-2017. The plane-oriented earthquake clusters due to magma injections beneath the Klyuchevskoi Cluster in 2000-2017 were 3D mapped, yielding some refinements on the locations of crustal magma chambers, as previously set forth by Fedotov et al. (2006, 2010, 2011), and being in overall agreement with the concept as proposed by (Koulakov et al., 2013) which considers dynamic variation in melt saturation in the magmatic plumbing system of these volcanoes. The estimated relative amount of magma stored beneath volcanoes as time passed ranges between $0.8 \%$ (Klyuchevskoi) and $72.9 \%$ (Shiveluch) in relation to the magma discharged onto the Earth's surface. One unexpected, and important for assessment of geothermal resources, result is that high-temperature hydrothermal reservoirs can be formed beneath active volcanoes due to active circulation at depth (down to depths of -10 to $-35 \mathrm{~km}$ abs.) without having recourse to extra heat sources of magmatic origin. Nevertheless, the presence of extra magmatic heat sources can enhance the geothermal potential.

\section{CONCLUSIONS}

An analysis of the distribution of plane-oriented earthquake clusters beneath the Klyuchevskoi Volcanic Cluster and Shiveluch Volcano yielded the following results.
(1) The primary magma source that supplies magma to the Volcanic Cluster is probably situated at depths of -165 to $-205 \mathrm{~km}$ beneath Klyuchevskoi Volcano and the zones of magma injection in the form of dikes and sills are higher; they are interpreted as crustal (C2) (between -31 and $-28 \mathrm{~km}$ ) and peripheral $\mathrm{C} 1$ (between -1 and $+2 \mathrm{~km}$ abs.) magma chambers.

(2) Tolbachik Volcano is characterized by injections of dikes in the depth range between -8 and $-1 \mathrm{~km}$.

(3) The injection of magma beneath Bezymyannyi Volcano occurs in the form of sills in the depth range between -2 and $+2 \mathrm{~km}$; it may be hypothesized that a peripheral magma chamber is situated there. It is supplied with magma along dikes from the $\mathrm{C} 2$ crustal magma chamber beneath Klyuchevskoi.

(4) The injection of magma in the form of sills in the depth range between -4 and $-2 \mathrm{~km}$ abs. and between 0 and $+2 \mathrm{~km}$ is prevalent beneath Shiveluch, where the existence of two peripheral magma chambers may be hypothesized.

The volcanoes of the Klyuchevskoi Cluster serve as indicators of the geomechanical condition beneath them.

(5) The earth beneath Klyuchevskoi is generally dominated by horizontal radial tension (NF), while the zones of the crustal $(\mathrm{C} 2)$ and peripheral $(\mathrm{C} 1)$ chambers are under radial compression (RF).

(6) The earth beneath Tolbachik Volcano is dominated by horizontal tension with the maximum horizontal stress $\mathrm{S}_{\mathrm{Hmax}}$ being in the west-northwestern direction.

(7) The earth beneath Shiveluch and Bezymyannyi is dominated by horizontal compression.

Zones of magmatic fracking (hydraulic fracture due to injection of magma in the form of dikes and sills) within active volcanic plumbing systems produce permeable reservoirs with vertical extents up to $35 \mathrm{~km}$ (Klyuchevskoi) and up to $15 \mathrm{~km}$ across (Shiveluch), depending on the geomechanical condition of the host rocks. The iTOUGH2-EOS1sc simulation in application to Klyuchevskoi Volcano shows that hydrothermal circulation is occurring in these reservoirs with discharge rates between 12 and $106 \mathrm{~kg} / \mathrm{s}$ (between 20 and $140 \mathrm{MW}$ ), creating shallow high-temperature $\left(220-300^{\circ} \mathrm{C}\right)$ geothermal reservoirs (the top is at heights between 0 and $-1.5 \mathrm{~km}$ abs.) due to extraction of heat energy from zones of magmatic fracking and the associated host rocks. We consider the development of profile $\mathrm{X}-\mathrm{Z}$ thermo-hydrodynamic models with an EOS1sc Equation of State module along the survey lines shown in Fig. 1 as the first stage in the solution of the problem concerned with the conditions that favor the formation of hydrothermal systems near active volcanoes. The next stage envisages the transformation of XZ models into XYZ models and studies on the stability of the solution under different grid choices. 
Long-term hydrothermal circulation can produce conditions that are favorable for the creation of ore and oil-gas fields resulting from the geomechanical and thermal action of magma on the volcanogenicsedimentary host rocks and from interactions between water and rocks that contain organic matter of various origins.

\section{ACKNOWLEDGMENTS}

We express our sincere gratitude to E. Sonnethal (LBNL) for providing us with a collaboration license to use the iTOUGH2 v.7.1 software and to S. Finsterle (Finsterle Geoconsulting) for consultations in the use of iTOUGH2 v.7.1. We are grateful to I.F. Delemen', S.P. Pozdnyakov, and V.G. Rumynin for constructive remarks that helped to improve the paper.

This work was supported by the Russian Science Foundation, project no. 16-17-10008.

\section{REFERENCES}

Kirsanova, T.P. and Yurova, L.M., Some results from a hydrogeochemical study of the Tolbachik Dol and perspectives for the search for thermal water, Vulkanol. Seismol., 1979, no. 2, pp. 85-95.

Kiryukhin, A.V. and Sugrobov, V.M., Modeli teploperenosa $v$ gidrotermal'nykh sistemakh Kamchatki (Heat Transfer Models for the Kamchatka Hydrothermal Systems), Moscow: Nauka, 1987.

Kiryukhin, A.V., Delemen', I.F., and Gusev, D.N., Vysokotemperaturnye gidrotermal'nye rezervuary (Hig Temperature Hydrothermal Reservoirs), Moscow: Nauka, 1991.

Kiryukhin, A.V., Modelirovanie ekspluatatsii geotermal'nykh mestorozhdenii (Simulating the Exploitation of Geothermal Resources), Vladivostok: Dal'nauka, 2002.

Kiryukhin, A.V., Kiryukhin, V.A., and Manukhin, Yu.F., Gidrogeologiya vulkanogenov (The Hydrogeology of Volcanogenic Rocks), St. Petersburg, 2010.

Kiryukhin, A.V., Fedotov, S.A., and Kiryukhin, P.A., A geomechanical interpretation of the local seismicity related to eruptions and renewed activity on Tolbachik, Koryakskii, and Avacha Volcanoes, Kamchatka, in 2008-2012, J. Volcanol. Seismol., 2016, vol. 10, no. 5, pp. $275-291$.

Kiryukhin, A.V., Fedotov, S.A., Kiryukhin, P.A., and Chernykh, E.V., Magmatic plumbing systems of the Koryakskii-Avacha Volcanic Cluster as inferred from observations of local seismicity and from the regime of adjacent thermal springs, J. Volcanol. Seismol., 2017, vol. 11 , no. 5, pp. 321-334.

Makeev, A.M. and Krolevets, A.N., A computer program for the search for planes of 3-D clustering of earthquake hypocenters in Kamchatka, Vestnik KRAUNTs, Fiz.Mat. Nauki, 2011, Issue 2, no. 3, pp. 69-79.

Polyak, B.G. and Melekestsev, I.V., On the output of volcanoes, Vulkanol. Seismol., 1981, no. 5, pp. 22-37.
Fedotov, S.A., Magmaticheskie pitayushchie sistemy i mekhanizm izverzhenii vulkanov (Magmatic Feeding Systems and the Mechanism of Volcanic Eruptions), Moscow: Nauka, 2005.

Fedotov, S.A. and Zharinov, N.A., On the eruptions, deformation, and seismicity of Klyuchevskoy Volcano, Kamchatka in 1986-2005 and the mechanisms of its activity, J. Volcanol. Seismol., 2007, vol. 1, no. 2, pp. 71-97.

Fedotov, S.A., Zharinov, N.A., and Gontovaya, L.I., The magmatic system of the Klyuchevskaya group of volcanoes inferred from data on its eruptions, earthquakes, deformation, and deep structure, J. Volcanol. Seismol., 2010, vol. 4, no. 1, pp. 1-33.

Fedotov, S.A., Utkin, I.S., and Utkina, L.I., The peripheral magma chamber of Ploskii Tolbachik, a Kamchatka basaltic volcano: Activity, location and depth, dimensions, and their changes based on magma discharge observations, J. Volcanol. Seismol., 2011, vol. 5, no. 6, pp. 369-385.

Fedotov, S.A., Slavina, L.B., Senyukov, S.L., and Kuchai, M.S., Seismic processes and magma movement occurring during the Great Tolbachik Fissure Eruption of 19751976 and during the Tolbachik Fissure Eruption of 2012-2013 in Kamchatka Peninsula, Geofizicheskie Protsessy i Biosfera, 2014, vol. 11, no. 1, pp. 3-30.

Kiryukhin, A.V., Asaulova, N.P., and Finsterle, S., Inverse modeling and forecasting for the exploitation of the Pauzhetsky geothermal field, Kamchatka, Russia, Geothermics, 2008, vol. 37, pp. 540-562.

Kiryukhin, A., Analysis of magma injection beneath an active volcano using a hydromechanical numerical model (CFRAC), in EAGE conference "Horizontal wells", Kazan. 2017. doi 10.3997/22144609.20170047510.3997/2214-4609.201700475

Kiryukhin, A., Lavrushin, V., Kiryukhin, P., and Voronin, P., Geofluid systems of Koryaksky-Avachinsky volcanoes (Kamchatka, Russia), Geofluids, 2017. Article ID 4279652. doi 10.1155/2017/4279652

Koulakov, I., Gordeev, E.I., Dobretsov, N.L., et al., Rapid changes in magma storage beneath the Klyuchevskoy group of volcanoes inferred from time-dependent seismic tomography, J. of Volcanology and Geothermal Research, 2013, vol. 263, pp. 75-91. doi 10.1016/j.jvolgeores.2012.10.014

Magnúsdóttir, L. and Finsterle, S., iTOUGH2-EOS1sc: Multiphase Reservoir Simulator for Water under Suband Supercritical Conditions. User's Guide, LBNL7017E. 2015.

Pruess, K., Oldenburg, C., and Moridis, G., TOUGH2 User's Guide, Version 2.0, Lawrence Berkeley National Laboratory Report LBNL-43134, Berkeley, CA, 1999.

Shapiro, S.A., Microseismicity: A Tool for Reservoir Characterization, EAGE Publications, 2008.

Zoback, M.D., Reservoir Geomechanics, Cambridge: University Press, 2010.

Translated by A. Petrosyan 